\title{
Controversial topics
}

\section{To flush or not to flush? Comments on the chlorpropamide-alcohol flush}

\author{
W. Waldhäusl \\ 1. Medizinische Universitätsklinik, Division of Clinical Endocrinology and Diabetes Mellitus, Vienna, Austria
}

Flushing, nausea and some giddiness were observed in diabetic patients following their exposure to chlorpropamide and alcohol as early as 1959 , shortly after chlorpropamide's release for clinical use [1]. Some 20 years later this phenomenon, which undoubtedly does exist, has been restudied in detail and described as occurring more often in Type 2 (non-insulin-dependent) diabetes than in Type 1 (insulin-dependent) diabetes or in healthy man $[2,3]$. In particular, chlorpropamide-alcohol-flushing (CPAF) was seen to a greater extent (81\%) in patients with a family history of Type 2 diabetes [3]. Against this background CPAF was consequently used as a tool to define better the heterogeneity of Type 2 diabetes as well as the prognosis of the associated late complications $[2,4,5]$. These studies finally led to a controversy, which is reflected by the contributions to this issue of Diabetologia [6-8]. The major points of disagreement in the course of the debate focus on the usefulness of CPAF as a defined test procedure for studying the heterogeneity of Type 2 diabetes.

Trying to comment on the present state of the art of chlorpropamide-alcohol-flushing one rapidly becomes aware that 'flushing' is a relatively common phenomenon. It occurs for a variety of causes, which include chemical agents as well as a broad range of clinical conditions (Table 1), all of which finally lead to stimulation of vascular smooth muscle or vasomotor nerves. Thus "hot flushes" are the most frequent complaint associated with the menopause and occur in about $80 \%$ of women [9], but are also present in some rare clinical syndromes including rosacea and carcinoid tumours [10]. Among the compounds provoking flushing, alcohol [10], nicotinic acid [11], catecholamines [12, 13] and others [10] are well known. In addition, genetic and environmental factors affecting ethanol metabolism [14] may contribute to the occurrence of alcohol flushing. Therefore, accumulation of acetaldehyde, as seen following alcohol ingestion as well as during CPAF [15] and even more so after administration of disulfiram [16], has been thought to be responsible for flushing. This assumption is, however, subject to doubt as no re- lation was found between circulating acetaldehyde levels and the severity of flushing in ethnic groups which are genetically predisposed to flushing [17].

The underlying biochemical and/or neurological changes responsible for the induced vasodilatation are still unknown, although many compounds have been discussed as possible mediators of 'flushing' (Table 2).

Table 1. Compounds and clinical conditions associated with flushing

\begin{tabular}{llll}
\hline Compounds & \multicolumn{3}{l}{ Syndromes } \\
\hline$\beta$-adrenoceptor agonists & {$[21]$} & Carcinoid syndrome & {$[21]$} \\
Alcohol & {$[10]$} & Eating & {$[21]$} \\
Calcium carbamide & {$[18]$} & Excitement & {$[21]$} \\
Carbon monoxide & {$[20]$} & Mastocytosis & {$[10,22]$} \\
Chlorpropamide & {$[1,2]$} & Medullary carcinoma & \\
Disulfiram & {$[10]$} & of the thyroid & {$[22]$} \\
Glucose & {$[19]$} & Menopause & {$[9]$} \\
Glutamate & {$[10]$} & Non-insulin-depen- & \\
Griseofulvin & {$[18]$} & dent diabetes & {$[2]$} \\
$\beta$-lactam antibiotics & {$[10]$} & Rosacea & {$[23]$} \\
Metronidazole & {$[18]$} & Vipoma & {$[22]$} \\
Nicotinic acid & {$[11]$} & & \\
Pentagastrin & {$[20]$} & & \\
\hline
\end{tabular}

Table 2. Postulated mediators of flushing

\begin{tabular}{ll}
\hline Compound & Remarks \\
\hline $\begin{array}{l}\text { Acetaldehyde } \\
\text { Histamine }\end{array}$ & $\begin{array}{l}\text { Elevated during CPAF [15, 29] } \\
\mathrm{H}_{1} \text { and } \mathrm{H}_{2} \text { receptor blockers are required to } \\
\text { suppress a flush. Most likely a pharmacological } \\
\text { action only [12, 28] }\end{array}$ \\
Kallikrein & $\begin{array}{l}\text { Parallels flushing in patients with carcinoid tu- } \\
\text { mour [27] }\end{array}$ \\
Lysyl-bradykinin & $\begin{array}{l}\text { Mimics spontaneous flushes and is elevated } \\
\text { during adrenaline-induced flushes [13, 25] }\end{array}$ \\
Met-enkephalin & $\begin{array}{l}\text { Elevated during CPAF [30] } \\
\text { Thromboxane and prostacyclin are elevated } \\
\text { during CPAF [26] }\end{array}$ \\
Serotonin & $\begin{array}{l}\text { May or may not be elevated during flushing [12] } \\
\text { Substance P }\end{array}$ \\
\hline
\end{tabular}


Table 3. Reported prevalence of chlorpropamide-alcohol-flushing in Type 2 diabetic patients and healthy control subjects

\begin{tabular}{|c|c|c|c|c|c|c|}
\hline \multirow[t]{3}{*}{ Reference } & \multirow{2}{*}{\multicolumn{2}{|c|}{$\frac{\text { Type } 2 \text { diabetic patients }}{\text { Prevalence }}$}} & \multirow{2}{*}{\multicolumn{2}{|c|}{$\frac{\text { Control subjects }}{\text { Prevalence }}$}} & \multirow{3}{*}{$\begin{array}{l}\text { Chlorpropamide } \\
(\mathrm{mg})\end{array}$} & \multirow{3}{*}{$\begin{array}{l}\text { Sherry } \\
(\mathrm{ml})\end{array}$} \\
\hline & & & & & & \\
\hline & $(\%)$ & $(n)$ & $(\%)$ & $(n)$ & & \\
\hline Micossi et al. [32] & $33^{\mathrm{a}}$ & 108 & & 0 & 250 & 40 \\
\hline Köbberling et al. [33] & $\begin{array}{l}15.3 \\
17.7^{\mathrm{d}}\end{array}$ & $\begin{array}{r}131 \\
62\end{array}$ & 16.9 & 154 & $2 \times 250$ & 20 \\
\hline Leslie and Pyke [3] & $\begin{array}{l}81^{\mathrm{d}} \\
31^{\mathrm{e}}\end{array}$ & $\begin{array}{r}91 \\
143\end{array}$ & 10 & 60 & 250 & 40 \\
\hline Jerntorp et al. [34] & 65 & 70 & & 0 & $125-375$ & $8 \mathrm{~g}$ alcohol \\
\hline de Silva et al. [35] & $22^{\mathrm{b}}$ & 49 & $38^{\mathrm{c}}$ & 21 & 250 & 40 \\
\hline
\end{tabular}

After correction for placebo instead of chlorpropamide: ${ }^{\mathrm{a}} 17 \% ; \mathrm{b} \%{ }^{\mathrm{c}} \mathrm{c} 10 \%$.

${ }^{d}$ with, ${ }^{e}$ without first degree family history of Type 2 diabetes

$n=$ total number of subjects studied

One of the first agents thought to be responsible was serotonin, which is elevated in patients carrying a carcinoid tumour, but may or may not be elevated in plasma during flushing [12]. Furthermore, it has been suggested that flushing may be provoked by minute amounts of catecholamines [12], which possibly induce the release of vasodilating agents such as kallikrein [24] and lysylbradykinin [13]. This is of note as lysyl-bradykinin is able to mimic spontaneous flushes [25]. A role in flushing has also been suggested for a rise in histamine [12] as well as prostaglandin release [26]. As CPAF may be abolished by the opiate antagonist naloxone and flushing is mimicked by an analogue of the opioid peptide met-enkephalins it has been suggested that flushing results from an increased sensitivity to endogenous opiates [31]. From this overall pattern we have to conclude that many compounds may be able to provoke flushing and that the final cause of CPAF remains to be explored.

Against this background it also becomes obvious that the transient phenomenon of facial flushing, as it occurs in some non-insulin-dependent diabetic patients after drinking alcohol when ingesting chlorpropamide, requires strict definition and quantification. The difficulty in fulfilling these requirements becomes apparent if flushing is defined according to Webster's dictionary as 'a tinge of red or ruddy colour as produced on cheeks', or as the patient's subjective perception of a 'warm, tingling or even burning sensation in the face' [3]. This difficulty in describing the flush is also reflected by the statement of Groop et al. [8] that they were "unable to show significant differences between (previously) CPAF-positive and CPAF-negative patients regarding flush-score, rise in facial skin temperature and blood acetaldehyde'. It is this basic problem in standardizing a bioassay which explains the large discrepancies in the estimated prevalence of chlorpropamide-alcohol flushing in Type 2 diabetes (Table 3 ). Use of thermography may help to improve this situation [6], although the response to be observed is heavily de- pendent on initial cheek temperature $[33,36]$. Furthermore, dependence of CPAF on chlorpropamide dose contributes to problems in testing as well as the need for a 8-9 day exposure to chlorpropamide [6], which also increases the risk of hypoglycaemia and thus hampers the recruitment of the necessary numbers of healthy control subjects. The preponderant use of undefined amounts of sherry, with all its ingredients, instead of the compulsory use of a defined amount of alcohol, likewise does not help the standardization of the test. Attempts to improve these basic limitations of the CPAF concept have been further jeopardized by the observation that one can flush without a rise in skin temperature, while conversely, a rise in temperature may occur without visible flushing [37]. These difficulties in defining objective, i.e. measurable criteria for CPAF so far appear insurmountable and make any investigator completely dependent on the patient's interpretation of his subjective feelings. Thus at present the situation argues against employing CPAF as a means for the selection and definition of patients for epidemiological studies, as for example the evaluation of the frequency of late diabetic complications [5].

Surprisingly, less disagreement seems to exist as to the occurrence of CPAF in patients with Mason-type diabetes, i.e. mild familial diabetes with dominant inheritance [38]. Patients suffering from this syndrome displayed a relatively homogenous $57 \%-84 \%$ prevalence of CPAF [37], although again one contradictory study reported three out of four Mason-type diabetics to be CPAF-negative [39]. It may well be, however, that patients with Mason-type diabetes more often carry the fully developed trait for CPAF than do other non-insulin-dependent diabetic patients, and thus present a more homogenous group.

From the above one has to conclude that recruitment of CPAF-positive individuals is a tricky task if one starts with an otherwise undefined group of patients with Type 2 diabetes, as the definition of flushing is subject to considerable error unless new ways of standard- 
ization are designed to overcome the obstacles of subjective monitoring of CPAF. Fortunately, the risk of selecting a heterogeneous group of CPAF-positive patients seems to be considerably smaller in Mason-type diabetics [37] than in patients with Type 2 diabetes. Thus it appears reasonable to study patients from this more homogenous group in a collective effort to design a reproducible test of chlorpropamide-alcohol flushing. Dosage of chlorpropamide and alcohol per kilogram body weight may help in standardization of the test. Only when a reproducible test for CPAF is available can the clinically exciting speculations that CPAF-positive diabetic patients carry a smaller risk than CPAF-negative individuals of developing the dreaded late complications of diabetes be proved or disproved.

\section{References}

1. Signorelli S (1959) Tolerance for alcohol in patients on chlorpropamide. Ann NY Acad Sci 74: 900-903

2. Pyke DA, Leslie RDG (1978) Chlorpropamide-alcohol flushing: a definition of its relation to non-insulin-dependent diabetes. $\mathrm{Br}$ Med J 2: 1521-1522

3. Leslie RDG, Pyke DA (1978) Chlorpropamide-alcohol flushing: a dominantly inherited trait associated with diabetes. Br Med J 2: 1519-1521

4. Barnett AH, Pyke DA (1980) Chlorpropamide-alcohol flushing and large vessel disease in non-insulin dependent diabetics. $\mathrm{Br}$ Med J 2: 261-262

5. Leslie RDG, Barnett AH, Pyke DA (1979) Chlorpropamide-alcohol flushing and diabetic retinopathy. Lancet 1: 997-999

6. Johnston C, Wiles PG, Pyke DA (1983) Chlorpropamide-alcohol flush: the case in favour. Diabetologia 26:1-5

7. Hillson RM, Hockaday TDR (1983) Chlorpropamide-alcohol flush: a critical reappraisal. Diabetologia 26: 6-11

8. Groop L, Eriksson CJP, Huupponen R, Ylikahri R (1983) Roles of chlorpropamide, alcohol and acetaldehyde in determining the chlorpropamide-alcohol flush. Diabetologia 26: 34-38

9. Mully G, Mitchell JRA (1976) Menopausal flushing: does oestrogen therapy make sense? Lancet 1: 1397-1398

10. Wilkin JA (1981) Flushing reactions: consequences and mechanisms. Ann Int Med 95: 468-476

11. Levy RI (1980) Drugs used in the treatment of hyperlipoproteinaemias. In: Goodman LS, Gilman A (eds) The pharmacological basis of therapeutics. Macmillan, New York London Toronto, pp 834-847

12. Robertson JIS, Peatt WS, Andrews WM (1963) The mechanism of facial flushes in the carcinoid syndrome. Q J Med 31: 103-123

13. Oates JA, Pettinger WA, Doctor RB (1966) Evidence for the release of bradykinin in carcinoid syndrome. $\mathrm{J}$ Clin Invest 45: $173-178$

14. Vesell ES, Page JG, Passananti GT (1971) Genetic and environmental factors affecting ethanol metabolism in man. Clin Pharmacol Ther 12: 192-201

15. Jerntorp P, Ohlin H, Bergström B, Almér L (1981) Increase of plasma acetaldehyde - an objective indicator of the chlorpropamide-alcohol flush. Diabetes 30: 788-791

16. Sauter AM, Boss D, von Wartburg JP (1977) Re-evaluation of the disulfiram alcohol reaction in man. J Stud Alcohol 38: 1680-1695

17. Seto A, Tricomi S, Goodwin DW, Kolodney R, Sullivan T (1978) Biochemical correlates of ethanol-induced flushing in orientals, $\mathbf{J}$ Stud Alcohol 39: 1-11

18. Seixas FA (1975) Alcohol and its drug interactions. Ann Intern Med 83: 86-92
19. Hillson RM, Hockaday TD (1982) Facial and sublingual temperature changes following intravenous glucose injection in diabetics. Diabète Metab 8: 15-19

20. Fröhlich JC, Bloomgarden ZT, Oates JA, McGuigan JE, Rabinowitz D (1978) The carcinoid flush: provocation by pentagastrin and inhibition by somatostatin. N Engl J Med 299: 1055-1057

21. Oates JA (1980) Carcinoid syndrome. In: Isselbacher KJ, Adams RD, Braunwald E, Petersdorf RC, Wilson JD (eds) Principles of internal medicine. McGraw Hill, New York and Kogagusha, Tokyo, pp 476-479

22. Rabin D, McKenna TJ (1982) Clinical endocrinology and metabolism, principles and practice. Grune \& Stratton, New York London, pp 629-632

23. Marks R (1968) Concepts in the pathogenesis of rosacea. $\mathrm{Br} \mathrm{J}$ Dermatol 80: 170-177

24. Adamson AR, Grahame-Smith DG, Peart WS, Starr M (1969) Pharmacological blockade of carcinoid flushing provoked by catecholamines and alcohol. Lancet 2: 293-296

25. Fox RH, Goldsmith R, Kidd DJ, Lewis GP (1961) Bradykinin as a vasodilator in man. J Physiol 157: 589-602

26. Barnett AH, Koullapis EN, Nicolaides K, Pyke DA, Spiliopoulos AJ (1981) Circulating prostanoid levels, both basal and during the chlorpropamide-alcohol flush, in non-insulin-dependent diabetes. Clin Endocrinol 15: 499-505

27. Mason DT, Malmon KL (1966) Abnormal forearm vascular responses in the carcinoid syndrome: the role of kinins and kinin generating system. J Clin Invest 45: 1685-1699

28. Roberts LJ II, Marney SR, Oates JA (1979) Blockade of the flush associated with metastatic gastric carcinoid by combined histamine $\mathrm{H}_{1}$ and $\mathrm{H}_{2}$ receptor antagonists. $\mathrm{N}$ Engl J Med 300: 236-238

29. Barnett AH, Gonzalez-Auvert C, Pyke DA, Saunders JB, Williams R, Dickenson CJ, Rawlins MD (1981) Blood concentrations of acetaldehyde during chlorpropamide-alcohol flush. Br Med J 2: 939-941

30. Medbak S, Wass JA, Clement-Jones V, Cooke ED, Bowcock SA, Cudworth AG, Rees LH (1981) Chlorpropamide-alcohol flush and circulating met-enkephalin: a positive link? Br Med J 283: 937-939

31. Leslie RDG, Pyke DA, Stubbs WA (1979) Sensitivity to enkephalin as a cause of non-insulin-dependent diabetes. Lancet 1: 341-343

32. Micossi P (1981) The prevalence of chlorpropamide-alcohol flushing in non-insulin-dependent diabetics. Diabetologia 20: 510 (Letter)

33. Köbberling J, Bengsch N, Brüggeboes B, Schwarck $H$, Tillil $\mathbf{H}$, Weber M (1980) The chlorpropamide-alcohol flush. Lack of specificity for familial non-insulin-dependent diabetes. Diabetologia 19: $359-363$

34. Jerntorp P, Almér LO (1981) Chlorpropamide-alcohol flushing in relation to macroangiopathy and peripheral neuropathy in noninsulin-dependent diabetes. Acta Med Scand 656:33-36

35. DeSilva NE, Tunbridge WM, Alberti KGMM (1981) Low incidence of chlorpropamide-alcohol flushing in diet treated non-insulin-dependent diabetics. Lancet 1: 128-131

36. Wilkin JK (1982) Chlorpropamide-alcohol flushing, malar thermal circulation index and baseline malar temperature. Metabolism 31: 948-958

37. Harris M, Leslie RDG (1981) Chlorpropamide-alcohol flushing in diabetes. Diabetologia 21: 422-424

38. Tattersall RB (1974) Mild familial diabetes with dominant inheritance. Q J Med 170: 339-357

39. Dreyer M, Kühnau J, Rüdiger HW (1980) Chlorpropamide-alcohol flushing is not useful for individual genetic counselling of diabetic patients. Clin Genetics 18: 189-190

Professor Dr. W. Waldhäusl

Division of Clinical Endocrinology and

Diabetes Mellitus

1. Medizinische Universitätsklinik

Lazarettgasse 14

A-1090 Wien, Austria 